\title{
Citizen Entrepreneurship: A Conceptual Picture of the Inclusion, Integration and Engagement of Citizens in the Entrepreneurial Process
}

\author{
Jay Mitra ${ }^{1}$, Mariusz Sokolowicz ${ }^{2}$, Ursula Weisenfeld ${ }^{3}$, Agnieszka Kurczewska ${ }^{4}$, and Silke \\ Tegtmeier $^{5}$
}

\begin{abstract}
This conceptual and exploratory article aims to present a rationale for the engagement of citizens with the process and practice of, and research on new forms of entrepreneurship. We argue that this form of citizen engagement could enable a better alignment of entrepreneurial initiatives with economic, social and community priorities and to address issues of global import and of local interest in uncertain environments. To this end we posit that engaging citizens in the entrepreneurial process could facilitate agency at the collective level of people with their rights, duties and responsibilities, to identify, participate in, and govern with existing institutions, in meaningful economic and social activity in defined spatial environments. Our normative understanding of the entrepreneurial process involves the creation of business, social and public enterprises, the formation of which is led by entrepreneurs. Entrepreneurs are of course citizens of specific nation states, but their endeavors do not necessarily warrant the participation of the wider community of citizens in the entrepreneurial process beyond their receiving function as users of goods and services. We consider whether pro-active engagement in a variety of ways, as nurtured
\end{abstract}

\footnotetext{
${ }^{1}$ University of Essex, UK;

${ }^{2}$ University of Lodz, Poland

${ }^{3}$ University of Leuphana, Germany

${ }^{4}$ University of Lodz, Poland

${ }^{5}$ University of Southern Denmark, Denmark
} 
in the practice of Citizen Science or Citizen Economics projects, could strengthen the profile and substance of entrepreneurship to resolve critical economic, social and environmental concerns of our times.

We use the concept of the 'commons' and collective efficacy to argue for an understanding of entrepreneurship and innovation as a social good. We argue that Citizen Entrepreneurship (CE) is able to create new forms of collective organization and governance and derive economic and social value by addressing local issues arising from wide-spread phenomena such as inequality, social polarization, populism, migration, and the gradual erosion of democratic institutions. To do so citizens need to develop capabilities for engagement in the entrepreneurship process. Indeed, active engagement could lead to the achievement of capabilities for wellbeing and fulfilling lives which go beyond the acquisition of skills and competencies necessary to pursue a vocation or a career. We refer to and interpret three examples of collective entrepreneurial activity in different urban environments in European countries as models of CE highlighting what we see as a growing trend in the entrepreneurial substance of the 'urban commons'. We work towards the creation of a conceptual model with which to develop an understanding of a unique formulation of entrepreneurship.

\section{Keywords:}

Citizen entrepreneurship; citizen engagement; innovation; social good; capabilities; collective efficacy

\section{Introduction}

\section{Citizen Engagement}


Are citizens important for economic and social development? In any democratic society, this question may sound superfluous. We are likely to take for granted the rights, duties, and responsibilities of the citizen with a default assumption that carrying a passport, voting at an election or even being able protest, defines citizenship. The benefits (rights) that accrue from citizenship rights are buttressed by the requirements (duties) and expectations (responsibilities). However, citizenship understood merely as a mechanism of governance or as an instrument of democracy may be insufficient for determining its meaning or scope. The nurturing and sustenance of democracy may depend on the knowledge, skills, civic intelligence and moral integrity of all its citizens, as Vincent Ostrom (1997) argued. Add to that the idea of self-governance and the collective efficacy of 'the commons' representing citizenship in action, as developed by Elinor Ostrom $(2005,2014)$, and the ability to achieve 'capabilities' with which to fulfil individual and collectives hope, aspiration and well-being (Sen, 1993) that informs the Human Development Index of the United Nations, and we begin to consider a more nuanced, value-driven and potentially efficacious appreciation of citizenship.

In our fractured social and economic environments, made worse by the growing institutional sclerosis over issues that affect our lives so fundamentally, surface symptoms, systemic limits and structural disconnects straddle questions, inter-alia, of ecology, unequal wealth creation access and accumulation, and access to finance (Sharmer amd Kaufer, 2013). Furthermore, as Tims (2015) noticed, such processes as the growing strength of private capital in relation to public one (resulting in privatisation of public spaces and appropriation of commons), or what Sekera (2017) points to as the neglect of and the appropriation of public goods for private custodianship and gain, coupled with ineffective legal regulations, declining faith in the 
mechanisms of traditional democracy, or "marketization" of interpersonal relations and commercialisation of public life, all cause a depletion of urban commons. The disconnect and the social imbalance could perhaps be re-set by self-governance based on a coherent set of beliefs and crucially through the direct or indirect and competent engagement of citizens.

Citizen engagement is not a new phenomenon. Early work by Robert Chambers (1994), looks at how Participatory Rural Appraisal (PRA) entails the use of different approaches and methods to allow local people to share, augment, analyze and replicate their understanding of the essential conditions of their lives and physical circumstances, so that they can better plan for multiple eventualities. Applications range from natural resources management, agriculture, poverty and social programs, and health and food security. Various approaches and methods can be found in activist-oriented participatory research, anthropological field research with citizens, ecosystem analysis, and different forms of appraisal. While traditional field research is often 'imposed' on a community with data collection being typically done by outsiders, PRA uses a shared platform owned by local people who learn and use, a myriad of methods including "interalia mapping and modeling methods, transect walks, matrix scoring, seasonal calendars, trend and change analysis, well-being and wealth ranking and grouping, and analytical diagramming" (Chalmers, 1994; pg.953).

Other writers such as Cernea (1985) identified relevant sociological variables to articulate and inspire issues of gathering and acting on citizen feedback. The tide of genteel academic interventions and recommendations has given way to the increasing demand by citizens and civil society for a more pronounced voice in public decision-making. Governments have to some extent 
responded with both overtures and actions that reflect the needs of citizens emanating from the unravelling of the 'disconnects' referred to above. Demand and the supply has acquired a new found legitimacy of urgency of action not least because the rise of innovations in digital and mobile technology, including open and crowd sourcing, open data, virtual reality, 3-D printing, and artificial intelligence, has provided citizens with unprecedented opportunities to engage policy makers and private producers both at local and the international levels.

We can witness a rising tide in this form of engagement attracting institutional interest when citizen engagement became a strategic priority for the World Bank in 2013, with a corporate goal of achieving 100 percent beneficiary feedback by 2018 in all World Bank Group operations with clearly identifiable beneficiaries. The bank learnt key lessons from this exercise including, inter-alia: a) the need to go beyond citizen engagement and rethink the very model of governance; b) the understanding that engaging citizens can improve the delivery and quality of public services; c) the realization that empowering citizens to simply make their voices heard is not enough; d) and a recognition of global diversity in the new consciousness that it was advisable to rethink existing the limitations of approaches from North America and Europe being replicable or transferable to developing countries (World Economic Forum, 2016). The Organisation for Economic Cooperation and Development (OECD), one of the largest public policy think tanks in the world is a partner for civil society and citizens behind various movements and organisations, aiming to respond to the needs of their citizens by thinking about the route to collective intelligence particularly where technology plays a key role. This has led to the creation of the OECD's 'Better Life Index' which focuses on citizen engagement around people's quality of life. The creation of this Index was inspired by "Civic Tech" an idea developed in the USA, which connects a wide number of citizens, allowing them to access information, and create a space for dialogue and 
sharing opinions, harnessing collective intelligence ensuring better citizen participation in democracy.

The form of citizen engagement referred to above harbours the distinctiveness of a top down approach, with either government or a large organisation acting as the sponsor-catalyst and using its vast resources to drive an agenda. The role of the catalyst is crucial for any form of citizen engagement and our early forays into observing different $\mathrm{CE}$ projects reinforce this catalytic function. However, when we bring entrepreneurship into the equation, we are exploring the prospect of citizens not just participating or engaging with an initiative but taking responsibility for forming new organizational arrangements through their involvement. That suggests a level of civic competence and a motivation for contributing to or making decisions which brings citizens to the forefront of new organizational development without compromising the role of institutions and private entrepreneurs.

\section{Citizen Engagement as Entrepreneurial Action}

One way of fostering that civic competence and a better sense of self-governance is through entrepreneurship, but not as entrepreneurship as usual, as in a relentless tide of new venture creation and innovation for the sustenance of the holy grail of accelerated economic growth. Perhaps entrepreneurship in its broader Schumpeterian sense of prevalence and application across multiple economic and social functions needs what Tirole (2017) invests in the purpose of economics for the common good. If we wish to upgrade entrepreneurship to something more than the growth rate of start-ups by the few and embed it in a wider pool of social and economic activities, we might need to overcome the constraints of orthodoxy. We need to stretch our critical 
appreciation of entrepreneurship to a form of engagement that combines the innovative strength of producers and users with engagement in the creative dynamics of people as citizens. Our canon of knowledge on entrepreneurship fails to respect the collective wisdom of citizens who are also producers, users, parents, partners, children, and crucially, the collective set of individuals who have a purpose in their societies. What is produced, marketed and sold in the name of entrepreneurship is dependent on the absorption of goods, services, ideas and information by all citizens. However, entrepreneurial culture or framework conditions rarely embrace the role of citizens as pro-active participants in the entrepreneurship development process. So how could we create a new culture of Citizen Entrepreneurship (CE)?

CE means the involvement of citizens, as users, producers and collective governance gatekeepers, in the private, social, and public entrepreneurship process (Mitra et al., 2019). The formation and growth of an average business or social enterprise requires a definitive, efficacious act of establishing a new organization and its nurture, to buy and sell goods and services for purely business and/or social objectives. The citizen's involvement is at best transactional as a recipient of those goods and services. However, the emergence and presence of enterprises has, inevitably, an impact on the lives of people beyond the transactional market-based exchange. There are questions about the impact of the enterprises in the local environment, their use of the labour market, the security of the enterprises against crime, and the earning of social legitimacy coupled with the necessary valorisation of local social capital. These larger questions, in both clement and trying circumstances, draw the attention of the citizens to the gains or the fallout from the actions of the enterprise. Businesses respond with corporate social responsibility (CSR) and social enterprises fill the void in the community often arising from public, market or systemic failure. 
These actions remain within the province of the single enterprise taking such action. Citizens remain passive or vocal beneficiaries while all the evidence points to the entrenched limitations of reach of both CSR and social enterprise activity to respond to the larger questions because of their meta-level significance. At the meta level, the pragmatic engagement of citizens with ecosystem stakeholders could attempt to find better answers through innovative approaches to citizenengaged actions and organisations.

$\mathrm{CE}$ meets the enterprises and the institutions (governments, universities and other power brokers) at the cusp of economic, public or social provision and its communal receipt, where the meta-level significance of larger questions of the environment, labour market skills, the improvement of people's habitat or solutions to crime, come into play. CE promotes the idea of pro-active engagement of citizens, in the private, social, and public forms of new venture creation and growth made possible by productive social and economic projects. CE offers new ways of using technology, harnessing a common pool of financial, social and human capital, to address people's aspirations and needs. It could act as a meaningful antidote to decreasing levels of trust in institutions, businesses and governance processes in most countries around the world, enabling a realistic form of Aristotelian 'eunoia' or goodwill, 'arete' or virtuousness and objective transparency, and critical judgment or 'phronesis', essential for effective governance (Wynn, 2017).

Crucially, CE does not mean being evangelical about all citizens developing enterprise formation capabilities. Rather, it is about greater awareness, meaningful contact with entrepreneurial activities in society and engagement with entrepreneurs about choices for skills 
development and labour supply, valorization of financial and human resources, implications for the environment and local problem solving. Citizen engagement in entrepreneurial initiatives often find best expression in smart city projects such as the one in Copenhagen, Denmark regarded as the "smartest city" by the EasyPark Group (Copenhagen Capacity, 2018), in socially constructed programmes such as the Glasgow project on crime reduction initiated by a number of stakeholders with local families, victims and perpetrators of crime, or in the capacity development of rural artisans, performing artists and musicians through rural development initiatives in West Bengal, India by Bangalnatakdotcom (Mitra, 2019).

Our purpose here is to reflect on the prospect of citizen engagement in varied entrepreneurial processes and work towards a broad conceptual framework with which to explore the idea of CE.

\section{Towards a Conceptual Framework for CE}

In time honoured fashion, our objective is to suggest a set of broad explanations that could fit and elucidate observable facts especially in circumstances where the underlying cause may not have been discovered or defined. To assume that $\mathrm{CE}$ is a phenomenon would be adopting too positivist a perspective before examining facts, figures and dynamics. Neither is there any attempt to develop constructs but to find ways and means of telling a story, to rely on what Eisenhardt and Graebner, (2007) refer to as inductive theory building. Paraphrasing Eisenhardt's comments in Gehman et al.'s essay (2017) we walk through an open door without preconceptions of what relationships may obtain, but with some tools to prevent us losing our way, guessing at best about 
constructs but remaining sufficiently open minded to explore the possible application of different concepts with which to make early observe and interpretations of what CE could look like.

\section{Combinatorial Concepts}

We use a combinatorial approach to construct an essential framework for CE centred round an idea or an assumption of an extended form of entrepreneurship and innovation as a social good. Schumpeter as a public intellectual in the late 1920s and early 1930s offers unique insights into the social roots of the entrepreneur, the worker and the economy. We use these insights to advance our arguments about the social fabric of entrepreneurship and how it nurtures a sense of collective efficacy for citizens to be engaged with entrepreneurship. The possibility of entrepreneurial activity occurring in any environment necessitates an appreciation of the social embedding (Granovetter, 2017) as evinced in the importance of social networks enabling the harnessing of social capital. Social and institutional embeddedness also forms a base for linking the entrepreneurial process with the economics of proximity and with the prospect of exploring innovation as a social good. Other than market and price mechanisms of coordination of collective action, this form of socialization of economic activity appreciates reciprocity and proximity which takes a form of a geographical, cognitive, social and institutional character (Boschma, 2005; Torre and Rallet, 2005; Sokołowicz, 2015). Successful innovation needs to be diffused and absorbed in society, and whatever its economic benefits might be, its ultimate value tends lie in its capacity to generate social change.

We reinforce the idea of entrepreneurship and innovation as a social good by drawing on Elinor Ostrom's $(1965 ; 2014)$ concept of the 'commons' where citizens are guided by a notion of 
collective self-efficacy to achieve collective governance over the production, use, distribution and effective understanding of goods and services that affect their lives. We consider this form of collective efficacy as the basis of achieving what Amartya Sen $(1993,1997 ; 2008)$ refers to as a capabilities set for citizens to fulfil their aspirations and wellbeing in society through knowledge, skills, civic engagement and moral integrity. The framework facilitates entrepreneurship as a putative social movement of people where citizens can become directly engaged with the formation, development and growth stages of enterprises while addressing economic, social, and cultural disconnects that thwart their sustainability. The foundations for the framework as described, above are shown in Figure 1 below:

Figure 1: Foundations or Building Blocks for a Conceptual Framework

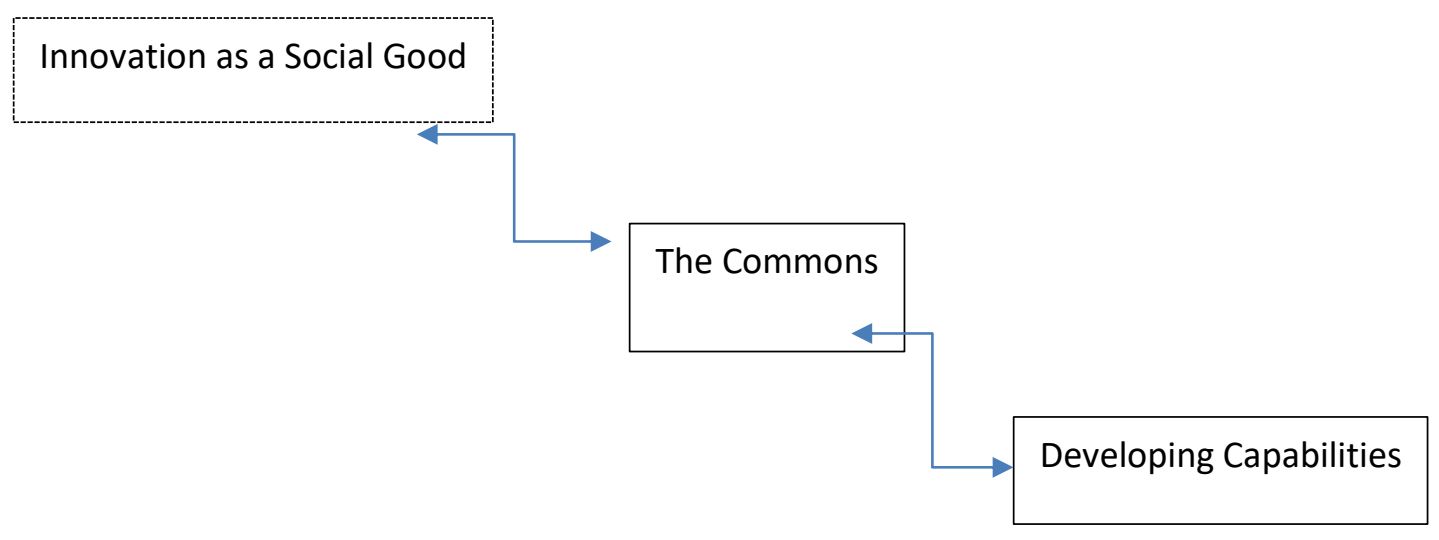

We borrow from well-established new practices particularly in Citizen Economics and Citizen Science where citizen knowledge and insight, and local experimentation enhance expert application to develop instruments of creative resolution of issues that matter at both the local and meta levels. 
Secondary data and the anecdotal evidence that we have seen so far point to the entrepreneurial citizen engagement in urban areas. The Scottish city of Glasgow's knife crime project managed through the Violence Reduction Unit, the PlatzProjekt in Hanover, Germany, or the Socially engaged project in Lodz, Poland, are all good examples of urban-centred citizen engagement. However, other examples from across the world such as the Art for Life project in West Bengal, India, shows that citizen engagement in entrepreneurial projects cutting across both rural and urban lines. We limit our focus in this paper to reflections on the urban setting in Europe.

\section{An Overview of the Combinatorial Literature}

\section{A Schumpeterian Perspective}

At a time of another great recession and between 1925 and 1932 at a time of much controversy in Germany, Schumpeter wrote a major series of articles for The German Economist covering four topics - tax levels and public budgets, wages and unemployment, business booms and the underlying nature of capitalist society. Economists and entrepreneurship researchers tend to concentrate attention on the first three missing the import of for example Schumpeter's 1930 essay, 'Change in the World Economy' his 1932 article, 'Enduring Crisis, and his 1927 piece, 'The Function of Entrepreneurs and the Interest of the Worker'(published in a labour magazine). In the first essay he dismisses the idea of limits to technological progress, asserting instead the value of fresh opportunities and new innovations interacting with old ones to produce accelerated progress. In the second he argues about fitting novel ways of doing things to be fitted into the organism of the existing economy (McCraw, 2007). What matters is the long-term interest of entrepreneurship and innovation, and in that longer term the interests of entrepreneurs and workers are identical because the motivation for high earnings for entrepreneurs is a function of the translation of 
innovations into actual production, raising the standard of living of all. Jobs resulting from successful innovations and the creation of new firms are a social gain for both the firms and society.

As firms evolve and small entrepreneurial firms become large establishments the entrepreneurial function alters, a different type of entrepreneur emerges, one who is dependent on the innovative suggestions of specialists to create new products, generate new processes, amend business models and form new types of organisations. Extending this idea, as society evolves changing needs offer opportunities for alternative forms of organisations to meet economic and social needs at the wider societal level.

\section{Social Embedding and Proximity}

The possibility of entrepreneurial activity occurring in any environment necessitates an appreciation of the social embedding (Granovetter 1985, 2017) as evinced in the importance of social networks enabling the harnessing of social capital which is further enhanced by cultural, political, religious, and wider institutional influences on entrepreneurship, and the underpinning themes of trust and legitimacy. Social and institutional embeddedness also forms a base for linking the entrepreneurial process with the concept of proximity which dates back to the Marshallian concept of industrial districts (Marshall, 1920). Other than market and price mechanisms of coordination of collective action, this school also appreciates reciprocity and proximity which takes a form of a geographical, cognitive, social and institutional character (Boschma 2005, Rallet and Torre 2005, Sokołowicz 2015).

\section{Multiple and Hybrid forms of Enterprise}


Despite the advances in a kind of social theoretical formulation of entrepreneurship, research and policy has tended to rely on linear, formulistic and conditional conceptions of economic growth as evinced in small firm growth, employment, and knowledge creation (Acs and Audretsch, 2006). Comparable entrepreneurial function is performed by those who provide public goods and services (public sector entrepreneurship), which recognizes the role of the state in being pro-active wealth creators. Mazzucato (2015) has argued that government investment in, for example, technology, medicine, and energy, has driven wealth creation by sharing risks with the private sector. Where both market prospecting by private enterprise and state intervention at times of market failure, have bypassed social and community problems, the Third Sector, in the form of social enterprises, has created alternative forms of self-sufficiency to address such social needs (Nicholls, 2010). New technology and especially digitalization have made possible a form of open or even 'free' innovation (von Hippel, 2017), which connects producers with users as part of a new 'sharing economy'. At a social level we find high-impact capital from a variety of sources with wide reach and for previously hidden forms of activity, or the monetization of personal assets, time and other resources. These include crowd-based networks (as opposed to centralized institutions and hierarchies), the blurring of lines between personal and professional activities, and the dramatic change underway in the nature of employment under the broad banner of 'flexible labour', resulting in an obfuscation of formal or full-time and casual labour. CE is not restricted to any specific form of entrepreneurial engagement. However, in recognizing multiple and hybrid forms of enterprise development, CE offers opportunities for citizens to make choices and consider a direct or indirect agency function.

\section{The Entrepreneurial Urban Commons}


Perceiving entrepreneurship from our broad and combinatorial perspective could mean considering its place in and purpose as belonging to the whole society and not just to its economy. If we understand entrepreneurship as "acting differently" and if we mean CE as a domain of public realm, referring to the concept of urban commons can cognitively broaden our understanding of entrepreneurship. The latter concept refers to goods which are used by many actors simultaneously. This collective character of commons could cause problems because of overexploitation or free rider dilemma. However, urban commons include a wide range of urban goods: from parks, squares, streets, gardens and other public spaces, through a range of services offered in the city, such as public transport, water supply, health care and energy infrastructure, to scarce and hardly measurable urban resources such as the atmosphere of life in the city, the culture of functioning of various communities and subcultures of urban environments or urban identity.

The Bologna Regulation is an interesting enactment of the urban commons based on the notion of the city as a common. Referred to as the 'Bologna Regulation on Public Collaboration for Urban Commons' (De Nictolis, 2014) it was adopted by the city towards the end of 2014. It provides opportunity to explore different collaborative approaches to the management of certain types of urban space and property (including both public and private property) for a period of one year. The regulation is one product of "The City as a Commons" project supported by Fondazione del Monte di Bologna e Ravenna (www.fondazionedelmonte.it) but is an idea that is also being taken up by other Italian towns and cities.

The way in which urban commons is defined is not entirely clear. Regulation seems to be more about creating new or alternative collaborative (and co-management) arrangements between 
city administrators, 'active' citizens, and private property owners for managing certain kinds of space within the urban area. The definition from the Bologna Regulation defines urban commons as the mix of tangible, intangible and digital goods that citizens and the local administration recognize to be functional to the individual and collective wellbeing through participative and deliberative procedures. While working for them, citizens share responsibility with the local administration for the care and regeneration of the commons to improve the collective capacity for enjoyment of the commons.

The collective character of urban commons implies their three important characteristics: 1) Large number of users, 2) Diversity of the needs of commons' users (related to the allocation of different values of commons by different city users); and 3) The necessary means of cooperation and integration of many groups of city users in order to produce and consume common resources, optimally.

The above-mentioned characteristics underpin processes that result in the emergence of new approaches to commons management, sharing, protection and development, especially when there is systemic or market failure. Traditional government agencies often find it difficult to offer sustainable solutions to problems associated with the provision of physical and financial resources to keep public spaces, urban greenery, public transport infrastructure, community and cultural centres at a satisfactory level. Creeping privatization of the urban commons as an alternative to the public deficit sometimes ends up in the tragedy of many urban commons as a result of weakly or poorly regulated space. In these circumstances, more and more urban citizens take joint initiatives to deliver these goods "themselves", creating cooperative and collaborative structures of 
governance. Among such structures, referred to by Foster and Iaione (2016) as the 'commons institutions', we can point to, for example, community gardeners, business improvement districts (BIDs) and community improvement districts (CIDs), neighborhood park groups and park conservancies, and neighborhood foot patrols. Such an approach to govern the urban commons demands, however, new democratic design principles, such as horizontal subsidiarity, collaboration and polycentrism. These principles call for the reorientation of public authorities away from a monopoly position over the use and management of common assets and toward a shared, collaborative governance approach. In consequence, the role of the public authority becomes that of coordinator and mediator in co-design processes, while the citizens become proactive actors of urban change. Active citizenship means that urban inhabitants are participating not only passively in the public life of the city, but also in co-creating the city, mobilizing and using available resources and opportunities. In this sense, city officials and staff are tasked to assist, collaborate, and provide technical guidance (data, legal advice, communication strategy, design strategies, sustainability models, etc.) to enable themselves to manage, mediate, and coordinate the ecosystem. The collaborative agenda delivers an entrepreneurial urban ecosystem, in which the citizens play a key role. Scientific, technical and social innovations help to foster the creation and use of new knowledge.

A caveat about the limitations of the idea of the urban commons stems from the possibility of citizen engagement in entrepreneurial processes in emerging economies, mainly in Asia and Africa. There, large rural populations and their needs often provide for the best platforms to develop CE initiatives. As the 'Art for Life' project in West Bengal shows, harnessing and nurturing the wealth of neglected talent in traditional forms of music, dance, weaving, and street 
theatre in relatively poor rural districts can generate opportunities for both enhanced artistic work and a means of creating new forms of collaborative enterprise (Bhattacharya, 2020).

\section{Creating Knowledge and Capabilities for Citizen Engagement}

Systemic or market failure might generate a reaction for citizen intervention. It may also take the form of pro-active action to nurture and garner the benefits of economic, cultural, personal and social value creation. Realising the benefits of a CE centred 'commons' suggests that citizens require a capability set. There is always a need for a process for generating knowledge somewhere and that knowledge must be embodied in some sort of socially useful technology for it be absorbed and replicated in any way and in any place. Absorption, valorization and replication of knowledge and technology must retain some sort of public and social goods dimension in terms of being widely available to be of maximum social benefit, and there must be some ability on the part of recipients or users to adapt the technology to their conditions and needs (Dalrymple, 2003). Making this happen is the knowledge, skills, civic intelligence and moral integrity of all its citizens (Ostrom, 1997) coupled with idea of self-governance, well-being and the collective efficacy of 'the commons' representing citizenship in action (Ostrom, 1965; 2014). How are these skills to be developed and how can such knowledge serve the wellbeing of people to determine its social good outcome?

Adopting and adapting Sen's Capabilities Approach $(1993,1997,2008)$ allows us to connect the knowledge creation prospect with people's aspirations and sense of well-being, what Sen refers to 'functionings'. These 'functionings' could include autonomy, self-acceptance, growth and purpose in personal life to positive relationships and positive feelings of happiness. In 
entrepreneurial terms these 'functionings could be translated as creating and growing one's own enterprise to achieve autonomy through to deriving benefits from that enterprise as a consumer or co-producing goods and services as a user-producer (von Hippel, 2017). Emergent entrepreneurial identities of citizens using crowd-based platforms for ideas and resource generation enabled especially by new digital technologies (McAfee and Brynjolfsson, 2017) are a feature of our times. If we add to that the prospect of combining individual enterprise creation with crowd based structures for their input to meta level issues addressing disconnects in our economic and social lives we could create new social or civic identities for entrepreneurship development. These new identities are a manifestation of collective efficacy, which draw from a 'commons based' soft infrastructure, the resources necessary to achieve those 'functionings'. The outcome is the formation of a Capabilities Set which is an aggregation of the individual's own capabilities, the socially created ones of status and network or social embedding and the external capabilities or the abilities to function that depend on human or social relationships.

\section{The Urban Context}

Extended, combinatorial entrepreneurship has begun to surface significantly in urban environments. Cities are hotspots for sustainable futures: globally, over $50 \%$ of the population live in urban areas, with problems regarding carrying capacity and social justice. But cities also provide space for experimenting with alternative futures. A core challenge is social polarization (Swyngedouw et al 2002) emerging from the certain trends of globalization and market liberalization inspired urban policy makers to compete for capital, creative class and technology. Investigating five cases of European cities, Moulaert et al. (2001: 100) identified "a shift from (local) social to (local) economic policy, a 'new' elite coalition formation favouring private sector 
agents and 'new' forms of state entrepreneurialism that include large-scale urban development projects and city marketing“. Technology-driven and business-dominated policies often endorsed in theory and followed in practice - lead to increased polarization of citizens. Nearly twenty years on, we face urgent problems related to the dominance of the market logic and to a lack of a sustainability logic driving creativity, opportunity identification, resource mobilization and venture creation or development. Social innovation initiatives are caught in the friction between economic and social values and are subject to the usual efficiency paradigm. While ,sustainable cities' is one of the seventeen Sustainable Development Goals (SDG) of the United Nations, studies of urban social innovation show a variety of approaches and successes. CE turns this idea of purely state-led or free market, corporate led reorganization of the urban industrial space into the reality of a citizen-led or citizen inclusive recreation of an urban commons space.

\section{Antecedents of Citizen Economics and Citizen Science}

We borrow from well-established new practices particularly in Citizen Economics and Citizen Science where citizen knowledge and insight, and local experimentation enhance expert application to develop instruments of creative resolution of issues that matter at both the local and meta levels.

Public Recognition of the primary importance of the economy as an issue for citizens has emerged for reasons which we have identified above. But citizens appear to have little agency and authority, resulting in a democratic deficit in economic policy and decision- making. The Royal Society of Arts (RSA, 2016) in the United Kingdom and its Citizens Economics Council point to 
economic literacy, transparency, democratic accountability, and creativity (as in finding novel resolutions of problems) as the four deficiencies which block answers to questions about:

a) Understanding the goals of an economy.

b) Who should the economy serve?

c) What are the trade-offs we must make in deciding between different priorities?

d) Can policy be derived from evidence alone?

e) What about values, assumptions and judgements plus the application of evidence based social science?

The capability for answering these questions and exploring citizens' values can be achieved through deliberation and debate but crucially through empowerment, collaboration, and by engaging, receiving and informing citizens.

Some examples of emergent models of deliberative dialogue between citizens and decision- makers in policy in UK include the 'NHS Citizen', a deliberative engagement process that has involved citizens in a conversation about the strategic direction of the National Health Service NHS) or the Sciencewise project, an embedded government-funded public engagement programme which has delivered 54 dialogues in partnership with 32 government departments and agencies over a period of 12 years. (RSA 2016).

In well-established projects on ornithology, conservation of residential ecosystems and other scientific research projects, Citizen Science engages a dispersed network of volunteers to assist in professional research using methodologies developed collaboratively with professional researchers through crowd sourcing and other means (Cooper et al., 2007; Dickenson and Bonney, 
2012; Wynn, 2017). Our conceptualization embraces the Citizen Science construct of volunteer involvement in entrepreneurship research but introduces an activist dimension in economic and social project development initiatives.

Citizens in $\mathrm{CE}$ projects are engaged users, producers and providers equipped with an entrepreneurial capability set of knowledge, competencies, civic intelligence and integrity in polycentric settings. Their collective minds set and efficacy for engaging with entrepreneurship in various guises best manifest themselves in the realization of scalable projects that can harness diverse interests and capabilities. Region-wide or urban projects that accommodate individual and collective interest to solve problems and generate new organizational arrangements are often the most appropriate vehicles making CE work.

We build an exploratory model of CE based on earlier approaches. Our model of CE encompasses multiple local actors, activists, local governments, consultants and organizations. Our work should contribute to an in-depth understanding of the mechanisms and the potential of CE. We propose a transformative agenda for entrepreneurship and innovation for economic and social change in Europe and elsewhere that involves engagement with communities of citizens and shared knowledge creation (Weisenfeld and Hauerwaas, 2018). Figure 2 below provides for a diagrammatic configuration of our conceptualization. 


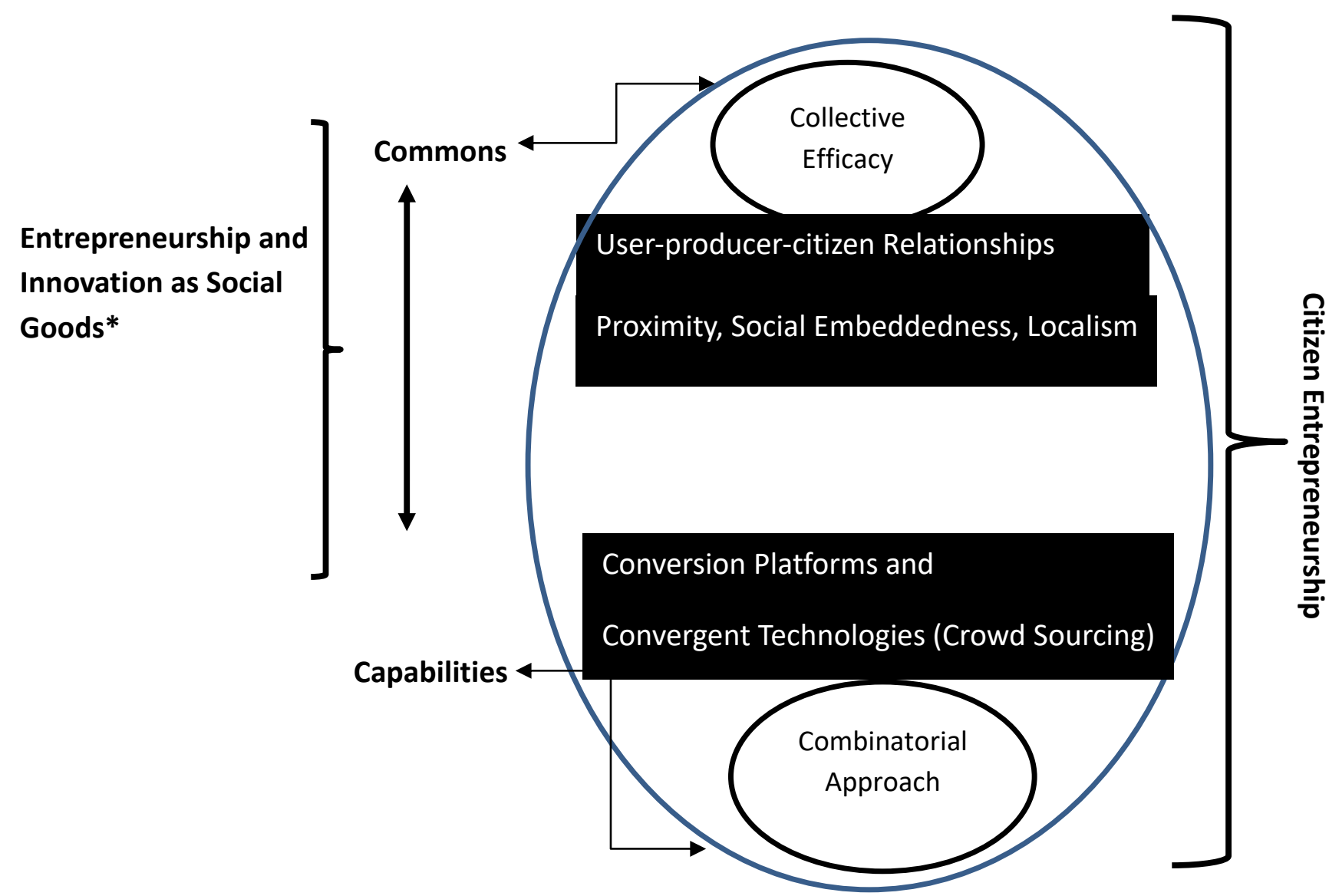

Early observations and Possible Research Questions

We refer to three programmes which we interpret as CE projects ${ }^{6}$. Our overview of the combinatorial literature and early observations of $\mathrm{CE}$ in practice raises three possible research questions outlined further down.

\section{The Nature and Scope of CE}

The PLATZProjekt (or the PLACEProject) is an urban experimental field to try out peoples' ideas for different ways of living, working, sharing, and organizing. It explores

\footnotetext{
${ }^{6}$ The information for the three projects has been drawn from respective websites for the project, and from informal discussions with the project managers.
} 
'prefigurative entrepreneuring', enacting of people's visions through the practice of entrepreneurship, which deviates from mainstream notions of entrepreneurship. PLACEproject is a container village providing space for experimentation, for active and participatory bottom up development. The project's multiplier effect spawned many more projects, became known in the city and beyond via media reports, and has been designated as one of several exceptional, exemplary projects for future urban development in Europe. Since 2014 different social and cultural projects test and realise their ideas of alternative living and working models. Some examples are a Café, a mini-sized eco-hiking hotel, a sewing studio, an inclusive refugee-project, a massage box, a clothes-swapping shop, and a DIY-beer brewery.

ProjectZero is a citizen-led societal renewal innovation which aims to enable the region of Sonderborg with approximately 77,000 inhabitants to become zero carbon by 2029 (The Guardian 2015). It engages the citizens as co-designers of the Smart Zero Carbon Sonderborg's ambition to implement integrated solutions with comprehensive learning and introduce new ICT-based energy information. The project was launched in 2007 as a joint venture between the citizens, politicians and businesses of the municipality of Sønderborg. Its holistic approach includes Public Private Partnership, green technologies, geothermal solutions, established business including Danfoss and Linak, participation and changing the mindset and a new thinking by and for citizens. The map in Figure 2 below shows the location of Sonderborg, an important consideration in the evolution of its ecosystem.

Socially Engaged (pl. Społecznie Zaangażowani) is the non-profit organization with the aim to induce social engagement of and for local communities of the Stare Polesie borough in Lodz, Poland. The founders and leaders of Socially Engaged are a couple, Agnieszka and Szymon, 
who lives in the Stare Polesie with their rich professional experience as social activists and in managing NGOs. The diversity of projects is notable, ranging from ecological ones (e.g. protecting urban greenery), through the education of youths in need, to cultural ones. The binding factor is the borough of Stare Polesie. During first three years 'Socially Engaged' existed as an informal group of people with common goals and shared values. The founders' understanding of entrepreneurship is broad as they define it as a purposeful human activity, connected with fulfilling needs of life in the borough. They also mention that it is their role to add an entrepreneurial element to all the ideas and projects which are brought to and realized through their project. The ideas for actions are given by life and situations they encounter when interacting with citizens, and further catalyzed by the city.

These early sketches of what could be described as CE type activities prompt us to ask our first research question:

$\boldsymbol{R Q}$ 1: What evidence can we find about the nature and scope of CE in different urban environments?

\section{Collective Endeavour, Collective Efficacy and Developing Capabilities for Citizen Engagement}

Beyond sheltering the individual projects, the PLACEproject explores structure- and community building and alternative forms of using open spaces. The project is thus seen as an enrichment for the whole city in terms of new entrepreneurial forms of economic, cultural and social offerings. The application for funding gave some temporary stability to the collective endeavour. A successful application provides institutional recognition (Barinaga, 2017) with the 
PLACEproject gaining public legitimacy by being located within the city. From the beginning, the cultural attitudes supported diversity, communality, and experimentation, forming part of an evaluative space for the cultivation of citizen entrepreneurial capabilities. A form of holistic involvement was another method of inculcating an entrepreneurial capability set where people felt they could be informed participants in achieving their 'functionings'; alongside fulfilling their collective goals.

In Sonderborg, the projects have been developed and described by the eight working groups that included participation from housing associations, tenants, project coordinators, IT solution partners, private companies, the municipality, education and research experts. Three projects, ZEROfamilies, the ZEROhome program and Test an EV were designed to generate solid outcomes results inspiring others and achieving the collective 'functionings' target of close to the 50\% CO2-reduction since 2007. To ensure collective involvement, Sonderborg joined a common platform with other Danish cities which provides information about the ambitions of the participating urban commons, and allows for regular exchange, sharing of experiences and inspiration, as part of the EU SmartEnCity project.

With reference to the Socially Engaged project in Lodz, Poland, the Association has established the Old Polesie Joint Cooperative as well as a community center run only by the activists. The place is attended by approximately 200 children and youth from the surrounding area, and on a smaller scale, by adults. It also serves as a venue for meetings and small cultural events, as well as a place of contact with the association's board of directors, which is increasingly perceived as an "intermediary" between the office and the citizens in the day-to-day business of 
the neighborhood 'Socially Engaged' works to foster and strengthen the local identity of all businesses and social initiatives in the district. Among other products, they published tourist guides and created an urban field game, "Discover Old Polesie" (included in the regional education program at the local primary school). The social activists are perceived as reliable partners in the dialogue with the authorities, and it has been possible to develop a certain model of cooperation with the municipality. Being a kind of broker, the association has the capacity to gather opinions about the real needs of the inhabitants and local businesspeople, as part of an urban commons. Although the activists concentrate primarily on urban greenery and the quality of public spaces alongside accessibility of public services around the main square, they also advocate the inclusion in the urban debate of the issue of creating a large socio-cultural center in the borough. Activists present a long-term vision of economic and social development of the Old Polesie that could be triggered by a creation of a center with open spaces for both cultural and business activities. This demonstrates an acute awareness of the fact that civic action cannot take place without an entrepreneurial approach and cooperation with the business community.

These initial observations of collective endeavour, collective efficacy and capability development lead us to our second research question:

$\boldsymbol{R Q} 2$ What constitutes collective efficacy or collective endeavor and how do citizens develop capabilities to engage entrepreneurially to solve socio-economic problems of global significance but of local import? 
Our three examples of $\mathrm{CE}$ in practice are realized in urban environments. The developments would be in keeping with the rapid concentration of livelihoods in cities, often because of higher levels of availability of financial and technological resources. However, our cases reveal a greater interest among their people for a form of social networked based capability development to address local concerns of global significance - the choice of sustainable habitats, the ecological imperative, mobilisation of local art and cultural resources alongside the need to stem urban decay. This choice is predicated upon the need to articulate a new vision for social legitimacy that reinvents the agenda for life, work and play. We find that in each of these environments collective endeavor enables stakeholders to figure out catalysts for transformation. To explore this urban commons factor further we could consider a third research question.

$\boldsymbol{R Q}$ 3: Is CE activity essentially urban in character? If so, what are the peculiar urban characteristics of CE?

\section{Concluding Observations and Implications}

\section{A New Passage to Scholarly Opportunity}

Unlike the usual discourse on stakeholders which revolves round the role of formal institutions in particular ecosystems, we find the early involvement of citizens in all aspects of shaping their ecosystem - from envisioning, to addressing surface symptoms, to testing systemic limits and structural disconnects (Sharmer and Kaufer, 2013). This focus on catalysts for change and an engaged citizens' platform provides for the evaluative commons space in which to develop novel capabilities for achieving individual and collective 'functionings' (Sen, 1993, 2008). The 
individual's own capabilities, the social ones of status and network embedding and the ability to function on the basis of strong human relationships (Foster and Handy, 2009) allow for the realisation of collective capabilities. Critically, they empower citizens to act not just as participatory observers of change but as emergent, entrepreneurial designers of their social and working lives.

Our conceptual framework and research questions underscore the development of an epistemological objectivity, and a virtuousness, the Aristoteian 'arete' that stretches beyond nontechnical critiques of current institution provision because they mobilsie resources for their own, new collective institutions. Through direct involvement our citizen entrepreneurs are less dependent on just primary sources of knowledge, developing a capacity for expertise in critical judgment (Aristotelian 'phronesis) acquired through association and collaboration with a range of different talents, ideas, creativity and scientific expertise.

Another unique capability afforded by networked and direct participation is what Aristotle referred to as 'euonia' or goodwill among and with fellow citizens. In being involved in identifying problems and mobilizing a collective efficacy for finding solutions, they come close to a form of methodological transparency akin to ones shared by scientific and technological communities of interest.

Through new forms of collective engagement and organization, we can see the prospect of extending the domain of entrepreneurship research to beyond "the scholarly examination of how, by whom, and with what effects opportunities to create future goods and services are discovered, 
evaluated, and exploited" (Venkataraman, 1997; Shane and Venkatraman, 2000) to the scholarly examination of how and with which effects opportunities to create future organisations for the social good are discovered, evaluated and exploited through the collective agency of citizens. Critically, our study opens possibilities for a new, epistemological approach to engaging with entrepreneurship, its meaning, functionality, and value. The unfolding of agency across different economic and social actors, and through new forms of user-producer-citizen relationships, should attract new arenas for entrepreneurship research, and help with the locating of entrepreneurship at the centre of social and economic policy making.

\section{Informing Local and Regional Development}

Our study brings the citizen into the heart of local and regional development, thereby enhancing the understanding of institutional frames, local needs, necessities, and opportunities. By identifying the key factors for employing $\mathrm{CE}$ as a driver for urban transition, our research sets in motion a citizen-based entrepreneurship research and development platform that could accommodate different forms of research of plural value to the society in which it takes place. We find that through CE, citizens become engaged in addressing local problems and making use of local opportunities. Where CE involves citizens from idea creation through to implementation stages of both commercial and citizen-based activities and where such projects are not restricted to individuals or groups of experts concerned with enterprise or social innovation, it reduces the tensions between private, public and social enterprise and the differentiated values they generate. We find that where the citizens, exercise collective efficacy as users, consumers, producers, and voters, they can engage with the formation, development and growth stages of the enterprises together with the state in acts of collective governance. This results in the avoidance of a fixation 
on entrepreneurship as a vehicle for growth and the cultivation of the practice of entrepreneurship as economic and social development.

Building on our conceptual framework and carrying out empirical work we hope to inform research and policy development all over Europe and elsewhere to try and help counter the uncertainties of fragile institutional environments. 


\section{References}

Acs, Z.J. and Audretsch, D.B. eds., 2006. Handbook of entrepreneurship research: An interdisciplinary survey and introduction (Vol. 1). Springer Science \& Business Media.

Barinaga, E. (2017), Tinkering with space: the organizational practices of a nascent social venture. Organisation Studies, Vol. 38 No. 7, pp. 937-958.

Bhattachrya, A. (2020). Art for Life: Intangible Cultural Heritage as a tool for Entrepreneurial Development in India in Mitra, J (ed). Indian Entrepreneurship and Innovation - The Current State of Affairs. New Delhi: Springer. (Forthcoming)

Boschma, R., 2005. Proximity and innovation: a critical assessment. Regional studies, 39(1), pp.61-74.

Bujalski S., 2018. Zielone Polesie wyróżnione. Miejska Pracownia Urbanistyczna z prestiżową nagrodą [Green Polesie awarded. Urban Planning Studio of Lodz with a prestigious award]. “Gazeta Wyborcza” 14.01.2018.

Cernea, M. M. (1985). Putting People First: sociological variables in rural development. Oxford University Press.

Chambers, R., 1994. The origins and practice of participatory rural appraisal. World Development, 22(7), pp.953-969.

Cooper, C., Dickinson, J., Phillips, T. and Bonney, R., 2007. Citizen science as a tool for conservation in residential ecosystems. Ecology and Society, 12(2), 1-11.

Dalrymple, D., 2003. September. Scientific knowledge as a global public good: Contributions to innovation and the economy. In The role of scientific and technical data and information in the public domain: proceedings of a symposium: 35-49. Washington DC: National Academies Press.

De Nictolis, E. (2014) Bologna Regulation of the Urban Commons. LabGov.City. December, 18; available on: https://labgov.city/theurbanmedialab/bologna-regulation-on-public-collaboration/ (last accessed on 20 May, 2020).

Dickinson, J. and R. Bonney, 2012. Introduction. Citizen Science: Public Participation in Environmental Research. Eds J. Dickinson and R. Bonney. Ithaca: Cornell University Press. 1-14.

Eisenhardt, K.M., 1989. Building theories from case study research. Academy of Management Review, 14(4), pp.532-550.

Eisenhardt, K. M., \& Graebner, M. E. (2007). Theory building from cases: Opportunities and challenges. Academy of Management Journal, 50, 25-32.

Foster, S.R. and Iaione, C., 2015. The city as a commons. Yale Law. \& Policy Review., 34, p.281.

Gehman, J., Glaser, V. L., Eisenhardt, K.M., Gioia, D., Langley, A., and Corley, K. G. Finding Theory-Method Fit: A Comparison of Three Qualitative Approaches to Theory Building. Journal of Management Inquiry 2018, Vol. 27(3) 284 -300. 
Granovetter, M., 1985. Economic action and social structure: The problem of embeddedness. American journal of sociology, 91(3), pp.481-510.

Granovetter, M., 2017. Society and economy. Cambridge: Mass., Harvard University Press.

Losik J. (2018). Co zmieni się na Polesiu? „Brakowało zieleni, całe osiedle było zabetonowane” [What will change in Polesie? „There was a lack of greenery, the whole housing estate was of concrete". "Gazeta Wyborcza Łódż” 30.11.2018.

Marshall, A. 1920. Principles of Economics, 8th edition. Macmillan, London.

Mazzucato, M., 2015. The entrepreneurial state: Debunking public vs. private sector myths (Vol. 1). Anthem Press.

McCraw, T.K. 2007. Prophet of Innovation: Joseph Schumpeter and Creative Destruction, Cambridge, Mass. The Belknap Press of Harvard University Press.

McAfee, A. and Brynjolfsson, E., 2017. Machine, platform, crowd: Harnessing our digital future. WW Norton \& Company.

Mitra, J. 2019. Entrepreneurship, Innovation and Economic Development: An Introduction; Abingdon Routledge.

Moulaert, F., Salin, E. and Werquin, T., 2001. Euralille: large-scale urban development and social polarization. European Urban and Regional Studies, 8(2), pp.145-160.

Nicholls, A. 2010. The legitimacy of social entrepreneurship: Reflexive isomorphism in a preparadigmatic field. Entrepreneurship Theory \& Practice, 34, 611-633.

Ostrom, E., 1965. Public entrepreneurship: a case study in ground water basin management (Doctoral dissertation, University of California, Los Angeles).

Ostrom, E. 2014. Collective Action and the Evolution of Social Norms Journal of Natural Resources Policy Research, 6(4), 235-252 .

Ostrom, V. 1997. The Meaning of Democracy and the Vulnerability of Democracies: A Response to Tocqueville's Challenge, Ann Arbor: University of Michigan Press.

RSA (2017). Economics for Everyone: Prospectus of the Citizens Economics Council, RSA Reports. June. Available on https://medium.com/rsa-reports/economics-for-everyoneda08028262a1\#.4pc9uqb95 (last accessed on 20 May, 2020).

Scharmer, C.O. and Kaufer, K., 2013. Leading from the emerging future: From ego-system to ecosystem economies. Berrett-Koehler Publishers.

Schumpeter, J. A. 1927. The Function of Entrepreneurs and the Interest of the Worker in Der Arbeitgeber 17 pp. 166-170.

Schumpeter, J.A. 1930. Change in the World Economy, Der deutsche Volkswirt 4 (1929-30) pp.1729-1733. 
Schumpeter, J.A. 1931. Enduring Crisis in Der deutsche Volkswirt (1931-32; pp. 418-421).

Sekera, J. (2017). Presentation at Institute for Innovation and Public Purpose University College London, December 12, 2017.

Sen, A., 1993. Capability and Well-being. In Nussbaum, M. and Sen, A. (Eds.), The quality of life. Oxford: Clarendon Press.

Sen, A., 1997. Editorial: Human capital and human capability. World Development.

Sen, A., 2008. Capability and Well-being in Hausman, D.M. (Ed.), The philosophy of economics: an anthology. New York: Cambridge University Press.

Shane, S., and S. Venkataraman (2000) The Promise of Entrepreneurship as a Field of Research. The Academy of Management Review, Vol. 25, No. 1: pp. 217-226.

Sokołowicz M. E., and Zasina, J. 2013. The role of culture as a stimulator of transforming industrial cities into creative ones. Case study of Lodz, Poland. "1 Economics \& Management: Proceedings of the 3rd International Conference of Young Scientists EM-203". Lviv: Lviv Polytechnic Publishing House, pp. 128-133.

Swyngedouw, E., Moulaert, F. and Rodriguez, A., 2002. Neoliberal urbanization in Europe: largescale urban development projects and the new urban policy. Antipode, 34(3), pp.542-577.

Tirole, J. (2017). Economics for the Common Good, Princeton and Oxford: Princeton University Press.

Torre, A. and Rallet, A., 2005. Proximity and localization. Regional studies, 39(1), pp.47-59.

Venkataraman, S. (1997). The distinctive domain of entrepreneurship research: An editor's perspective. In J. Katz \& R. Brockhaus (Eds.), Advances in entrepreneurship, firm emergence, and growth, vol. 3:119-138. Greenwich, CT: JAI Press.

von Hippel, E., 2017. Free Innovation by Consumers-How Producers Can Benefit: Consumers' free innovations represent a potentially valuable resource for industrial innovators. ResearchTechnology Management, 60(1), pp.39-42.

Walker, A. R. 1993. Lodz: The Problems Associated with Restructuring the Urban Economy of Poland's Textile Metropolis in the 1990s. Urban Studies 30(6), pp. 1065-1080.

Weisenfeld, U. and Hauerwaas, A., 2018. Adopters build bridges: Changing the institutional logic for more sustainable cities. From action to work set to practice. Research Policy, 47(5), pp.911923.

World Economic Forum (2016). Ten Lessons on Citizen Engagement by Soren Gigler. World Economic Forum, available on: https://www.weforum.org/agenda/2016/01/10-lessons-on-citizenengagement (last accessed 20 May 2020).

Wynn. J. (2017). Citizen Science in the Digital Age: Rhetoric, Science and Public Engagement. Tuscaloosa: University of Alabama Press. 